\title{
GOETHE AND HIS TEACHER JUSTUS CHRISTIAN VON LODER
}

We can find out in literature about Goethe nearly everything we want to, however, even historians of medicine know for too little about Loder. However, he had large merits in Germany as well as in Russia as a university instructor and organiser, as a doctor, researcher, collectioner and also as Goethe's friend, teacher and his colleague at the University of Jena. The relationship between too persons who were so different were joined for their common interest in anatomy. Those began in the fruitful scientific years in Jena; after a certain estrangement when Loder was working in Halle, their friendship was taken up again when Loder was in Moscow; at that time both of them were already old and grey-haired.

In their theses Verena Dotzauer and Alexander Impris have summarised the material about Loder's work in Russia and Germany and have made its evaluation in the aspect of time and environment. ' The author of this article (the third one about Loder) has enlarged the data collected by Impris and, based on materials from archives, has described some places of Loder's activities in Russia where be worked as a doctor and organiser. ${ }^{2}$

This study is dedicated to the memory of the author's "spiritual father" Dr. med. Heinz Müller-Dietz and his "doctor-mother" Mrs. Waltraud Müller-Dietz. Winner of Paul Stradin prize (1990), Heinz Müller-Dietz has crowned his life's work with his researches on Loder's activities. ${ }^{3}$

What really made Loder so famous, whom Goethe characterised as the nicest and most industrious person on Earth (geschäftigste und gefälligste Wesen von der $\left.W_{e l t}^{4}\right)$ ? Our impressions of him are that he used to be a small, shrewd man, nimble and eloquent and always ready to make friends.

Anton Friedrich Tischbein has portrayed Loder at the age of about 45 when he lived in Jena. He has depicted the graceful lecturer Loder during an anatomy class, which can be deduced from the blackboard in the background.

Justus Christian Loder was born in 1753 in Riga. His father was the fiduciary of pietist August Hermann Franke in Halle. In Riga, he was vicar of St. Jacob's church and rector of the tsarist lyceum. He brought up his son in the spirit of 
piety, teaching him belief in God, reason and healthy activities. Thanks to this kind of upbringing the son developed an uncomplicated, conservative "Weltanschauung" and uncompromised views on the good and bad. ${ }^{5}$

Loder received his medical education at the University of Göttingen, which, at that time, was the most progressive one in Germany; at its institutes there worked the best professors.

Heinrich August Wrisberg ${ }^{6}$ taught Loder anatomy, as well as obstetrics.

Loder attended lectures on anthropology and comparative anatomy with the comparatively young Johann Friedrich Blumenbach", whose famous collection of skulls left a deep and permanent impression on the future professor of anatomy.

Loder got very good training with August Gottlieb Richter ${ }^{8}$ - his future father in law, who tried to link surgery with internal medicine. Thanks to his wide praxis aurea, Richter was one of the richest men in Göttingen.

The famous Albrecht von Haller and the specialist in obstetrics Johann Georg Roederer founded one of the first obstetric institution in Germany - a hospital where obstetrics was taught. Loder established an obstetrics clinic according to his pattern in Jena.

Loder perfected his knowledge on state affairs with professor August Ludwig von Schlözer ${ }^{9}$, his future brother-in-law, who had been working for quite a long time at the Academy of Sciences in St. Petersburg. Loder attended lectures in classical philology with Christian Gottlob Heyne ${ }^{10}$, who was also supervisor of the library.

Possessing such a stable education, the 25 year old Loder, after half a year of his doctorate, was invited to Jena as head of the chair of surgery and obstetrics. It was said that Goethe himself had attracted the attention of Duke Karl August to the young scientist.

Loder spent a quarter of a century at his alma mater salensis, which profited a lot from Loder's ideas, diplomacy and several innovations and was grateful to this incessant organiser and brilliant teacher, also because of the great influx of students.

Loder organised not only an obstetrics clinic with a school of midwives, where students could go through practical tutoring (this could hardly be done anywhere else!) how to examine pregnant women and help them during labour and delivery; be also took care to renew the Anatomical theatre.

After this period, he set out for a study travel, which was the accepted thing at that time; after his doctorate, he did not have either money or time. In France, Holland and particularly in England where he had the opportunity to work with the outstanding anatomist William Hunter ${ }^{11}$, he received many impulses for surgical operations, the making of anatomical preparations and the formation of collections of such preparations. 


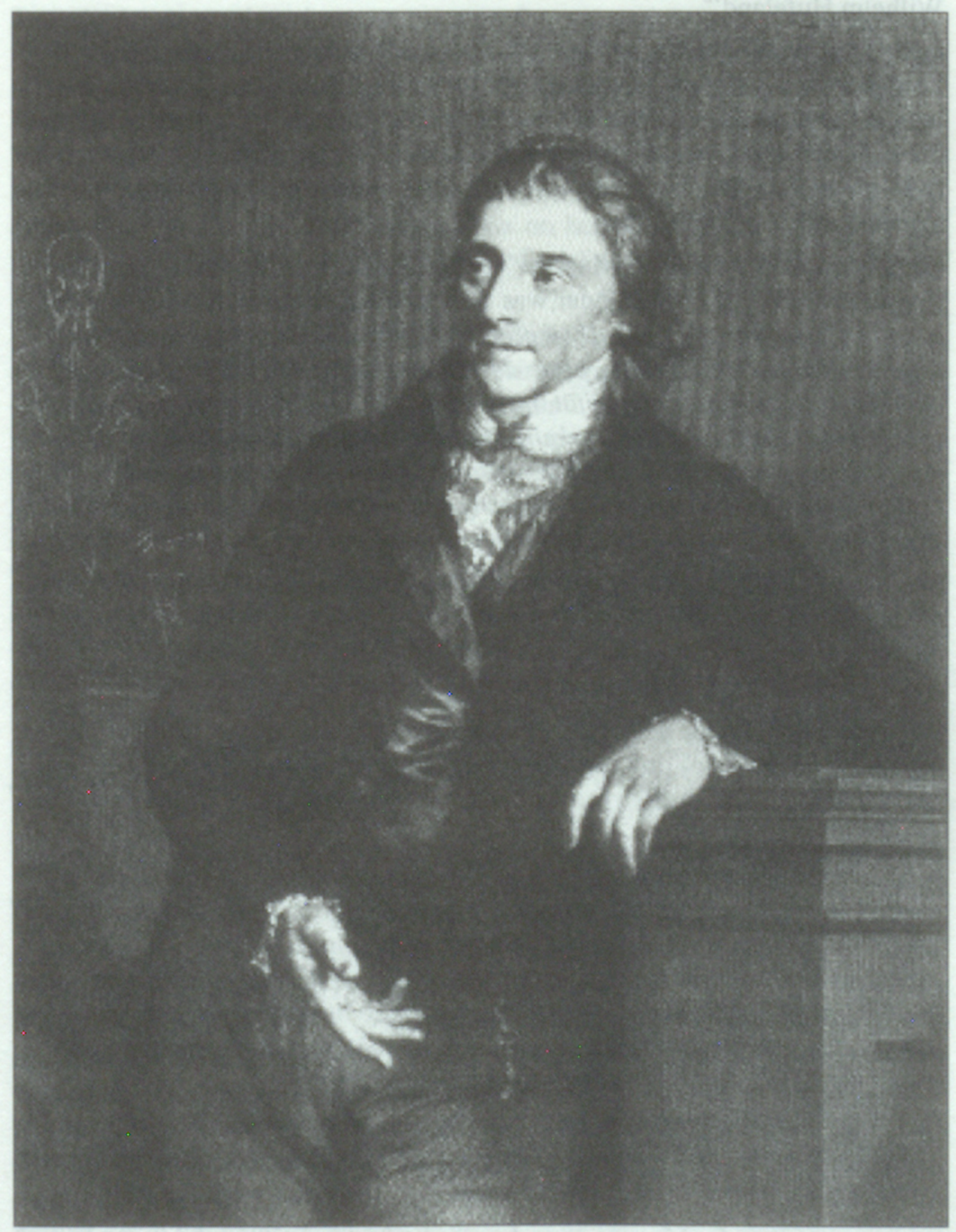

Justus Christian von Loder 
Notwithstanding the growing opposition, he managed to achieve the organisation of a small medical surgical hospital in Jena, which was headed by him together with his former pupil and closest friend - "macrobiotic" Christoph Wilhelm Hufeland ${ }^{12}$.

He mostly worked discretely giving advice unheeding the inner relationships in high schools and its personal policy. At his advice young philosophers, lawyers and doctors, with new and progressive ideas were invited to work there. They were those, who revived in Jena, or as Goethe used to say, in the twin town Jena-Weimar, classical times thus making it for a few years the spiritual centre of Germany.

Later on, while writing to Moscow economist Ludwig Heinrich Jakob ${ }^{13}$, the former protector of Halle, Loder was fully entitled to say: "Sie wissen es, daß ich über 20 Jahre in Jena dasjenige war, was Sie $<. . .>$ in Halle waren nemlich der wahre Kanzler, ohne den Namen davon zu führen. Es geschah nichts auf der ganzen Universität, im Disciplinar- und literarischen Verhältniß, es ward kein Institut errichtet, keine Stelle besetzt, niemandem eine Beförderung, Zulage $u$. dgl. ertheilt, ohne meine Mitwirkung und ohne meine Einleitung. Ich war der Vertraute und Correspondent des Herzogs von Weimar und seiner Minister." ${ }^{14}$ One of those ministers was Goethe.

Soon Loder formed friendly and familiar ties with Goethe and he became one of the most favoured conversation partners of Goethe. In his diary, Goethe mentions innumerable meetings with Loder in his flat in the Duke's Castle and at the court of Weimar as well as in joint trips and outings.

When in 1801 Goethe suffered from severe erysipelas of the face he mentioned as his friends not only Schiller, Herder and Voigt, but also Loder, who had all helped him in his recovery - "... über fernere böse Stunden hinauszuheben"15.

In a witty and merry message to Schiller, Goethe tells him that once, while visiting in Jena he received: "dieser Stapelstadt des Wissens und der Wissenschaften, zur Unterhaltung sowol, als zur geistigen und leiblichen Nahrung". He mentions Loder in this connection: "er gab furtreffliche Krebse, von denen ich Ihnen einen Teller gewünscht habe, köstliche Weine, einen zu amputierenden Fuß, einen Nasenpolypen, einige anatomische und chirurgische Aufsätze, verschiedene Anekdoten, ein Mikroskop und Zeitungen". ${ }^{16}$

Loder was a clever and charming conversationalist. He had grown up in the prosperous and lively trade town Riga and he knew how to enjoy the benefits of flesh and spirit.

Loder was host of a big and open house; he had been married twice to rich women. His second wife was the daughter of a famous and rich surgeon from Göttingen. Mrs Louise Loder and his children are often mentioned in Goethe's writings and letters. 
Those many foreigners who used to come to Weimar in order to visit the great poet Goethe often made an about turn of $23 \mathrm{~km}$ in order to stay with the hospitable Loder and see his exciting collections of anatomy preparations.

Loder's demonstrations in anatomy were famous and they didn't attract only students. The duchess-mother Anna Amalia, superintendent Gottfried Herder (also a trained physician), Friedrich Schiller (who had also studied medicine), brothers August and Friedrich Schlegel as well as other well-known persons were frequent guests at the anatomical theatre, which was lodged in narrow premises in an old city tower.

Alexander von Humboldt arrived in Jena on horseback from his Bayreuth's mine in order to acquire the knowledge of anatomy necessary for his trip to Western India.

Loder with his "cadavers" could make the Duke Karl August enthusiastic. Soon after his appointment Loder was sent to Weimar in order to explain the structure of the human brain to the Duke and Duchess Louise, to Goethe, Herder and the court physician Hufeland (the father of macrobiotics). He used a child's skull for this purpose. That was so unusual and also the situation at the Jena Anatomical theatre that even such a well-known newspaper (The privileged land newspaper of Hessen Darmstadt) described the situation as follows:

"Vor einigen Wochen mußte der Herr Prof. Loder in Jena auf Befehl S[eine]r Durchl[aucht] des Herzogs nach Weimar kommen, um Ihnen in Gegenwart des Leibarztes und verschiedener anderer Herren an Ihrem Hofe eine anatomische Demonstration über das Gehirn zu halten. Ein Beispiel von dieser Art ist uns noch nicht bekannt und es ist dieses vermutlich das erste. Ein paar Monate zuvor kamen schon der verwittweten Frau Herzogin Durchl. nach Jena, blo $\beta$ um sich dort eine anatomische Demonstration an ein paar Kindern auf dem dasigen anatomischen Theater halten zu lassen.

Noch vor ungefähr 15 Jahren hatte die Anatomie noch so viel Vorurteil in Jena gegen sich, daß Kaltschmied (Karl Friedrich Kaltschmied was professor of surgery in Jena before Loder) allemal, wenn ihm ein Kadaver gebracht ward, es mit dem Siegel der medizinischen Fakultät bezeichnen mußte, weil es sonst kein Student anzugreifen getraute, ohne für unehrlich gehalten zu werden. Werner Rolfink, der damals Professor der Arzneigelehrtheit war und daselbst die Anatomie zuerst in Gang brachte, kam darüber beim Pöbel in einen solchen Haß, daß man ihm auf der Straße mit Steinen nachwarf und daß die Deliquenten vor ihrer Hinrichtung sich es noch zur einzigen Gnade ausbaten, man möchte sie nach ihrem Tode nicht rolfinken (d.i. anatomieren) lassen. (In our days 'rolfinken' means stealing cadavers for dissection from graveyards.) Jetzt wollen zwar die gemeinsten und ärmsten Leute nicht gern ihre unehelichen Kinder anatomieren lassen, indes ist es schon genug zur Ehre der Vernunft, daß Herr Prof. Loder nicht allein seine Kadaver unbesiegelt vom Karren schleppen darf, sondern daß sogar Fürsten und Fürstinnen es für anständig und wichtig genug ansehen, die Maschine des menschlichen Körpers kennen zu lernen". ${ }^{17}$ 


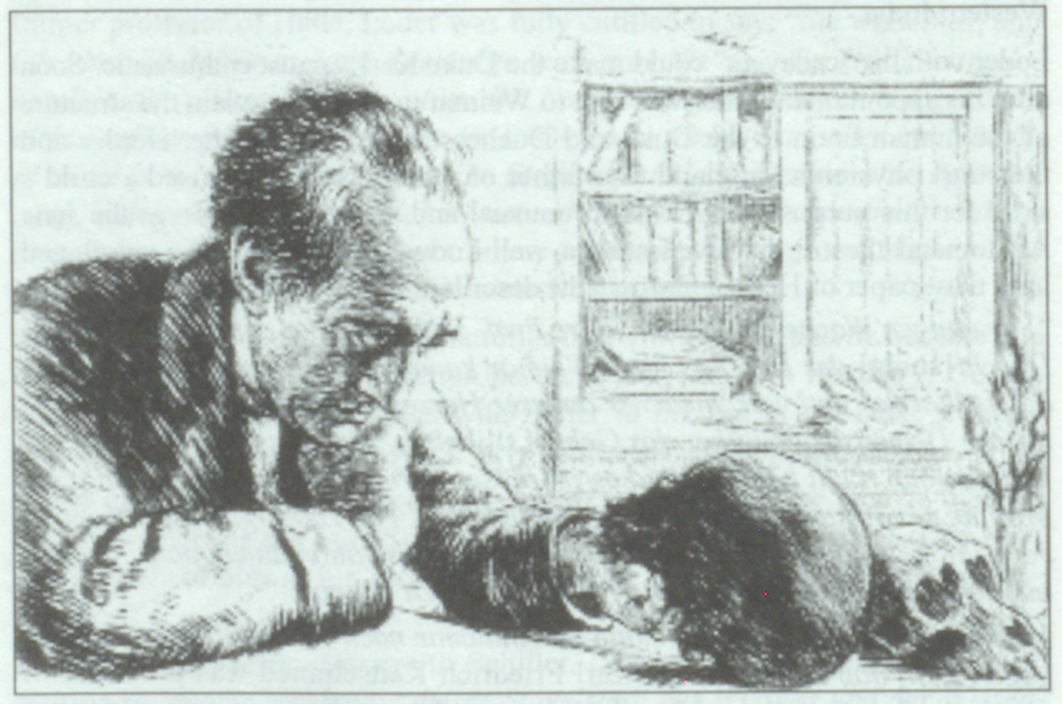

Johann Wolfgang von Goethe

(after etching from Prof. Karl Bauer) 
This is really a fine example how education was realised in practical life.

During the same month the Duke made use of his visit in Jena, where he had organised a banquet for the professors, who had come to view the anatomical preparation of Loder. Loder knew well enough what his Lord could be interested in for the Duke later wrote to his friend "Nach Tisch zeigte mir Loder an seinen außerordentlichen Präparaten, wie man methodice ein Kind machen könne" ${ }^{\text {18 }}$.

To Karl August who was experienced in sexual activities, such teaching was not necessary. His interest, however, in practical anatomical demonstrations did not disappear. At the beginning of 1795 wrote to Goethe:

"Es wird mir sehr angenehm seyn, wenn sich Loder morgen früh mit dem Gehirne und dem Kopfe herüber bemühen will; ich würde dann um $10 \mathrm{Uhr}$ zu Dir kommen und mit vielem Vergnügen der Demonstration beywohnen. Loder möge sich einrichten, alsdann bey Hofe zu Mittag zu essen" "19

Goethe was also present as a matter of fact and mentions this meeting in his "Annales": "Hofrat Loder demonstrierte das menschliche Gehirn einem kleinen Freundes-Cirkel in hergebrachterweise, in Schichten von oben herein, mit seiner ihn auszeichnenden Klarheit." ${ }^{20}$ After another demonstration, the Duke let Goethe know: "Ich bin gestern in Jena gewesen $<\ldots>$ Loder hat uns gestern entsetzlich vorgemetzelt..." 21

In the autumn of 1791 Goethe begins systematic studies in anatomy and also dissects corpses under Loder's guidance. His teacher testifies to it in one of his letters: "Eben ist Goethe hier und ich unterhalte ihn den ganzen Tag. Er ist auch ein treufleißiger Auditor in allen meinen Collegiis und wir haben nachher herrliche Unterhaltungen darüber" ${ }^{22}$. Since then Goethe's diaries and letters always contain news about his infatuation with anatomy.

For example in 1796, in March he writes: "Von 9 bis 10 Anatomie Männliche Zeugungs Theile von der Seite. Von 11 bis 12 verschiedene Operationen, besonders Steinschnitt" and some days later "Die Vena portarum an einem Kinde präparirt in Loders Auditorio".

Goethe continued with his anatomical studies with short interruptions till his old age. In Jena he studied conscientiously bones, muscles and tendous. After the first private class (privatissima) with Loder, Goethe wrote to the Duke:

"Mir hat er in diesen acht Tagen, die wir freylich $<. .>$ fast ganz dazu anwanden, Osteologie und Myologie durchdemonstriert. Zwei Unglïckliche waren, uns eben zum Glück gestorben, die wir dann auch ziemlich abgeschält und ihnen von dem sündigen Fleische geholfen haben." ${ }^{23}$.

Goethe needed knowledge in anatomy in order to teach drawing in Weimar. After already a few years, he could announce how successfully he had imparted his newly obtained knowledge about the human motion apparatus to young people. 
Goethe's reason for his studies of anatomy could be practical application - for the teaching of drawing, the Duke and his court, however observed his dissection corpses with curiosity and pleasant shivering.

Goethe, however, wanted more: while studying form, he wanted to enlarge and perfection his outlook of the naturalistic world. Did he also feel aesthetic pleasure? Did he regard the dissected corpse with the eye of an artist? In one of his letters to Mrs Stein he wrote: "Nun wird bald Loder kommen und es werden Anatomica zur Erholung und Ergötzung der Seele vorgenommen" ${ }^{24}$.

In his work "Wilhelm Meisters Wanderjahre" the poet depicts the honour of a student who has to dissect the beautiful arm of a woman who had probably once clasped a young man's neck. This very beautiful girl had drowned herself because of unrequited love.

Then anatomy took hold of the student. He grasped the instrument, but did not dare to dissect the girl - he kept standing and dared not to sit down. Disinclination for further mutilation of this beautiful creation of nature fought with the task the young man has set himself. What a romantic situation! Yet, how did it come into effect in practice?

In a letter for Major von Knebel - a friend of Goethe and the Duke - Loder mentioned Jena stable-man Heinrich. Loder foresaw that the stable would soon get a new stable-man, as he had saved his wife from a threatening abortion; she could have died of a kind of malignant fever.

Through saving this woman and protecting her from pregnancy, he missed a beautiful preparation. However Loder, the son of a pastor, continues: "Wie aber der Himmel doch nie das Gute ganz unbelohnt läßt, so hat er auch meine damalige Uneigennützigkeit damit belohnt, daß er es zugab, daß sich um Michael im Altenburgischen ein im 6ten Monat schwangeres Mädchen ersäufte, deren Cadaver ich aufs anat. Theater bekam. Ich ... conservierte dann den ganzen Leib mit dem Uterus und dem Kind in einem zinnernen Kasten voll Branntwein worin alles, wie Hr. Geh. Rath v. Goethe sagte, in feiner Sauce schwimmt." 25

Loder was a good doctor, who had a friendly attitude also towards very simple patients. Therefore, we should regard this frivolous attitude at the dissection table as a certain kind of protective mechanism. With grand and bragging speeches, they wanted to protect themselves against the threat of disease and death.

Dr. med. habil. Ingrid Kästner has described in detail how Goethes managed with the help of Loder to discover the human os maxillare. Therefore, I will not repeat the complicated nature of this discovery.

If we regard the teaching aids of the professors of that time, their collections and institutes, we have again to thank Goethe for essential progress in this field. Loder too, just like many professor of anatomy of that time, did not have enough cadavers for dissection and demonstration. He overcame this difficulty 
with conserved preparations from his collection, which had so much influenced the duke before. Collection of curiosities in the $18^{\text {th }}$ century was moved from the courts to the studies of scientists. Duke Karl August too parted from his "Kunstkammer". He bought some more collections and minerals and trusted Loder to put these in order and supervise them. Loder convinced the Duke to allow the rich material of the Jena University to be used for teaching purposes. That was of particular importance for the development of scientists, for the collection, which remained the possession of the inventory for ex. Loder's obstetric clinic and his medical hospital as well as the botanical garden of Jena - they all formed the future source of the University of Jena.

Nevertheless, the antiquated constitution of the Universities demanded that the professor's themselves took care of these teaching aids. Therefore Loder formed his own, personal collections of anatomy, pathology and anthropology; he bought them, exchanged and dissected. When he moved from Jena to Halle in 1803 , he took quite lawfully the whole collection with him, thus creating great losses to the University of Jena. His follower had to start from nothing tabula rasa. With this step Loder unwittingly encouraged the fact, that the university which was under the auspices of State Minister von Goethe obtained safe teaching aids and institutes, which were independent of the change of professors and remained permanently at these chairs.

Loder's departure from Jena and the loss of collections created certain coolness between the two "anatomical" friends, though not for long. When in August, 1805 , the Viennese craniologist Franz Joseph Gall arrived in Halle to deliver lectures, he lodged with Loder, who let Gall use his collections and also prepared them for demonstration. Gall taught that certain inclinations - he considered them to be 27 in number, beginning with the inclination to multiply, to steal, to write poetry; he thought them to be connected with certain parts of the cranium, which could be cognised through the exterior relief of the cranium. This theory was of great interest to Goethe. He had started his studies in anatomy with physiognomy and was used to "...das Gehirn von der vergleichenden Anatomie her zu betrachten" ${ }^{26}$. Goethe attended Gall's lectures, who, as he later remembered, was sitting next to his friend Loder. There was no talk about the previous discrepancy. Then Loder was lured away to Russia. He had close connections with this country. He had been born in Livonia as a subject of Russia. In the twenties Loder renewed his contacts with Goethe by sending him a rich collection of minerals from rare Siberian rocks. Loder died in 1832, at the age of 79 several months before his old friend Goethe passed away. Up to the last moment, new plans and projects carried him away. Even a week before his death he was appointed director of the German theatre in Moscow. Death crossed out the fulfilment of his age long wish - in his letters he had expressed his wish to obtain a post in Weimar, after having finished organising the hospital in Moscow. That would have again brought together the old fighters, both anatomy excellencies at the place of their common studies. 


\section{Justus Christian von Loder als Goethe Anatomie-Lehrer (Zusammenfassung)}

Diese Forschung ist von dem Autor seinem Doktorvater Professor Heinz E. MüllerDietz und der verehrter Doktormutter Frau Waltraud Müller-Dietz mit Dankbarkeit gewidmet.

Es werden hier die Beziehungen zwischen Goethe und Loder - seinem Lehrer, Freund und Kollegen an der Jenaer Universität geschildert. Die Begegnung und die Freundschaft der zwei beiden so verschiedenen Männer fand in Loders wissenschaftlich fuchtbaren Jahren in Jena statt. Nach gewisser Abkühlung wurden die Beziehungen wieder fortgesezt als Loder in Halle tätig war, und dann von Moskau aus wieder aufgenommen als die beiden - der Schriftsteller und der Anatom - schon im Greisenalter waren.

\section{References and Notes}

(WA - Johann Wolfgang von Goethe. Werke (Weimarer Ausgabe) Abteilung I Werke, Bd. 1-55. Abt. II Naturwissenschaften, Bd. 1-13. Abt. III Tagebücher, Bd. 1-15. Abt. IV Briefe, Bd. 1-50. Weimar $1887 \mathrm{ff}$.)

1 Dotzauer V. Justus Christian von Loder in Riga und Deutschland (1753-1806): Diss. - Berlin, 1987; Impris A. Christian Ivanovic (Justus Christian von) Loder in Russland (1807-1832): Diss. - Berlin, 1987.

2 Salaks J. J. Ch. v. Loders Krankenanstalten in Russland: Diss. - Berlin, 1991.

3 Müller-Dietz H., Salaks J. Dies ist mein Palladium: Justus Christian von Loders Sammlung anatomischer Präparate. - Riga, [1992]. - 127 S; Müller-Dietz H. Johann Wolfgang von Goethe und sein Anatomie-Lehrer Justus Christian von Loder // Sydsvenska medicinhistoriska sällskapets årsskrift.-1988.-2.-S. 59-76.

4 Letter to duke Karl August, November 4 1781. - WA IV. - Bd. 5. - S. 211.

5 Müller-Dietz H., W. Die Familie des Anatomen Justus Christian von Loder 1753-1832 // Der Herold. - 1988. - Bd. 12 (31. Jg.) - Heft 6. - S. 141-162.

6 Wrisberg Heinrich August (1739-1808), professor of anatomy and treatment in Göttingen (since 1764).

7 Blumenbach Johann Friedrich (1752-1840), professor of medicine, anthropology and comparative anatomy in Göttingen (since 1776).

8 Richter August Gottlieb (1742-1812), Dr. med. (1764), professor of medicine in Göttingen (since 1766), state councellor (since 1782).

9 Schlözer August Ludwig von (1735-1809), theologist and orientalist, professor of history in St. Petersburg (since 1761), member of the St. Petersburg Academy of Sciences professor (Staatslehrer) in Göttingen (since 1769).

10 Heyne Christian Gottlob (1729-1812), philologist of classical languages in Göttingen; superior librarian Secretary of Scientific Society.

11 Hunter William (1718-1783), anatomist, surgeon, obstetrician and famous collector. 
12 Hufeland Christoph Wilhelm (1762-1836), professor of medicine in Jena (from 1793), professor in Berlin (from 1801). Director of the hospital Charité, doctor of the court and state counsellor.

13 Jakob Ludwig Heinrich (1759-1827), professor of philosophy and national economy in Halle (from 1787), deputy rector (1801-1804).

14 Hasenclever A: Ungedruckte Briefe Justus Christian von Loders an den Nationalökonomen Ludwig Heinrich Jakob aus den Jahren 1810-1813 // Arch. Gesch. Med. - Leipzig, 11 (1918). - S. 302 f.

15 Tag- und Jahres-Hefte. - WA I, Bd. 35, S. 89.

16 Letter dated from 1800 July, 29. WA IV, Bd. 15, S. 91 f.

17 Hessen-Darmstädtische privilegirte Land-Zeitung. 19. August $1780 / /$ Hermann Bräuning-Octavio: Vom Zwischenkieferknochen zur Idee des Typus (Nova Acta Leopoldina. Neue Folge Bd. 18, Nr. 126). - Leipzig, 1956. - S. 7 f.

18 1780, July 7 - letter to Mayor Karl Ludwig von Knebel // E. u. R. Grumach (Hrsg.). Goethe. Begegnungen und Gespräche: Bd. 2. - Berlin, 1966. - S. 250.

19 Wahl H. Briefwechsel des Herzogs-Großherzogs Carl August mit Goethe: Bd. 1. - Berlin, 1915. - S. 196.

20 Tag- und Jahres-Hefte. - WA I, Bd. 35, S. 60.

21 Wahl $H$. Ebenda. Brief vom 8. Juli 1796.

22 Letter to F. J. Bertuh, dated from 1781, October 28. Anoted from Grumach, see note 18 .

23 Letter dated from 1781 November, 4. - WA IV Bd. 5, S. 211.

24 Letter dated from 1784 May, 7. - WA IV Bd. 6, S. 274.

25 Letter dated 1784, December, 23 - Goethe Museum Düsseldorf.

26 Tag- und Jahres-Hefte. WA I, Bd. 35, S. 201.

Juris Salaks, Dr. med., assoc. Professor Paul Stradin Museum of the History of Medicine Antonijas iela 1, LV 1360, Rīga, Latvia E-mail: museum2@mailbox.riga.lv 


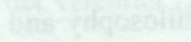

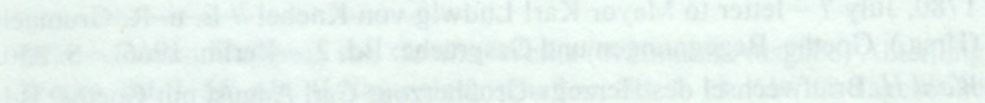

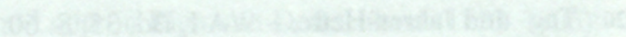



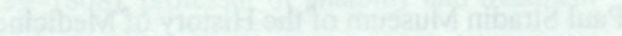

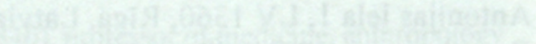

